\title{
PROFESIONALISME GURU PENDIDIKAN AGAMA ISLAM DALAM MENANAMKAN AKHLAK MULIA PESERTA DIDIK
}

\author{
Idhar \\ Sekolah Tingi Ilmu Tarbiyah (STIT) Sunan Giri Bima \\ idharrato123@gmail.com
}

\begin{abstract}
Abstrak
Guru profesional merupakan guru yang memiliki kompetensi dan tanggung jawab dari segi keilmuannya maupun metodologinya. Kemampuan tersebut sangat membantu para guru dalam mencapai hasil yang memuaskan dalam proses pembelajarannya. Seorang guru profesional memiliki persyaratan tertentu, seperti bekerja penuh, memiliki ilmu pengetahuan, ilmunya dapat diaplikasikan, ilmu didapat dari lembaga pendidikan, berprilaku baik, memiliki standar kode etik profesi. Disatu sisi pendidikan dewasa ini juga membutuhkan guru profesional dalam membangun generasi yang berilmu dan bermartabat dengan harapan tujuan pendidikan dapat tercapai dengan baik dan terarah. Jika pendidik mengedepankan diri sebagai pengajar yang berkualitas, maka dipastikan setiap pelaksanaan pembelajaran akan berlangung secara optimal dan akan berpengaruh pada hasil yang dikendaki. Dengan demikian, tanggung jawab guru termasuk guru pendidikan agama Islam sangat diharapkan keprofesionalannya dalam mendindik, membimbing dan mengajar peserta didiknya kearah manusia yang berilmu dan lebih khusus berakhlak mulia.
\end{abstract}

Kata Kunci: Profesional, Guru PAI, Akhlak

\section{Pendahuluan}

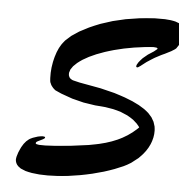

aat ini pendidikan agama menjadi sorotan yang tajam dari masyarakat. Hal ini adalah akibat dari banyaknya prilaku menyimpang peserta didik dan remaja pada umumya yang tidak sesuai dengan norma agama sehingga mendorong berbagai pihak mempertanyakan efektivitas pelaksanaan pendidikan Pendidikan Agama Islam di sekolah. Terkait dengan hal tersebut Muhaimin mengatakan "Selama ini Pendidikan Agama Islam sekaligus guru Pendidikan Agama Islam di sekolah sering dianggap kurang berhasil dalam menggarap sikap dan prilaku keberagaman peserta didik serta membangun moral dan etika bangsa. ${ }^{1} \mathrm{Hal}$ ini disebabkan oleh kompleksnya berbagai prilaku amoral dikalangan masyarakat seperti korupsi, kolusi, nepotisme, penyalahgunaan wewenang dan sebagainya, teramasuk dengan munculnya pilaku agresi negative peserta didik di lembaga sekolah mulai dari penyalahgunaan narkoba, miras, seks bebas hingga tawuran yang sangat mengganggu ketertiban dan keamanan masyarakat, telah menggambarkan pendidikan agama Islam di lembaga pendidikan, seakan tidak menjadi "tameng” penguatan moral seorang anak,

${ }^{1}$ Lihat Muhaimin, Pemikiran Aktualisasi Pengembangan Pendidikan Islam (Cet. 1; Jakarta: Raja Grafindo Persada), 154. 
dan bila ditilik secara sepesifik bahwa krisis multi dimensi yang melanda Indonesia sebenarnya bersumber pada menurunnya kualitas akhlak.

Padahal, kedudukan pendididikan agama Islam sangatlah penting dalam pembentukan akhlak peserta dilingkup pendidikan, mengingat pokok agama Islam, sebagaimana disebutkan dalam al-Qur'an tentang kemuliaan seorang yang memiliki akhlak mulia. Sehingga, maka masalah pendidikan agama Islam, baik ibadah, akhlak maupun unsur-unsur pendidikan Islam lainya dapat dipahami seoptimal mungkin, diamalkan secara tepat dan benar sehingga akan menghasilkan peserta didik secara cerdas, dan berakhlak mulia, insan yang berilmu sekaligus beriman. Sehubungan dengan hal tesebut, keberdaan komponen guru pendidik Agama Islam tentunya memiliki andil yang cukup besar untuk membelajaran nilainilai kegamaan secara optimal. Gurulah yang menjadi pelaku utama atau yang memberikan pendidikan secara langsung kepada peserta didiknya. Semua orang yakin bahwa guru menjadi kunci utama keberhasilan pembelajaran di sekolah. Guru sangat berperan dalam membantu perkembangan peserta didik untuk mewujudkan tujuan hidupnya secara optimal. Keyakinan ini muncul karena manusia adalah makhluk lemah yang dalam perkembangannya senantiasa membutuhkan orang lain. ${ }^{2}$

Demikian pula kedudukan guru sebagai tenaga profesional sebagaimana dimaksud dalam pasal 2 ayat (1) berfungsi untuk meningkatkan martabat dan peran guru sebagai agen pembelajaran dan berfungsi meningkatkan mutu pendidikan nasional. ${ }^{3}$ Guru memiliki tanggung jawab yang tidak ringan. Di samping dia harus membuat pandai peserta didik secara akal dia juga harus menanamkan nilai iman dan akhlak yang mulia. Untuk itu guru harus memahami dan mempunyai sifat-sifat positif dan menjauhi sifat-sifat negatif yang bisa memainkan perannya dalam memberikan pengaruh positif pada peserta didik di samping sarana dan prasarana, metode, starategi pendidikan dan juga para guru lebih khusus guru pendidikan agama Islam, harus memahami makna dan tujuan proses pembelajaran. Oleh karena itu, dalam rangka mengembangkan potensi peserta didik tidak luput dari peran serta guru sebagai pendidik profesional.

\section{Hakikat Profesionalisme Guru}

Profesionalisme guru adalah ide, aliran atau pendapat serta sifat-sifat profesional yang dimiliki oleh seseorang guru dengan mengacu kepada norma-norma profesional yang mempunyai makna penting yaitu:

a. Profesionalisme memberikan jaminan perlindungan kepada kesejahteraan masyarakat umum.

b. Profesionalisme merupaka suatu cara untuk memperbaiki profesi kependidikan.

${ }^{2}$ E. Mulyasa, Menjadi Guru Profesional Menciptkan Pembelajaran dan Menyenangkan (Cet. X: Bandung: RemajaRosdakarya,2011), 35.

${ }^{3}$ Undang-Undang RI No. 14 Tahun 2005 Tentang Guru dan Dosen (Jakarta: Cemerlang, 2007), 6. 
c. Profesionalisme memberikan kemungkinan perbaikan dan pengembangan diri yang memungkinkan guru dapat memberikan pelayanan sebaik mungkin dan memaksimalkan potensi. ${ }^{4}$

Kunandar menejelaskan bahwa Profesionalisme berasal dari kata profesi yang artinya suatu bidang pekerjaan yang ingin atau akan ditekuni oleh seseorang. Profesi juga diartikan sebagai suatu jabatan atau pekerjaan tertentu yang mensyaratkan pengetahuan dan keterampilan khusus yang diperoleh dari pendidikan akademis yang intensif. Jadi, profesi adalah suatu pekerjaan atau jabatan yang menuntut keahlian tertentu. ${ }^{5}$ Senada dengan itu, H.A.R Tilaar menjelaskan pula bahwa seorang profesional menjalankan pekerjaannya sesuai dengan tuntutan profesi atau dengan kata lain memiliki kemampuan dan sikap sesuai dengan tuntutan profesinya. Seorang profesional menjalankan kegiatanya berdasarkan profesionalisme, dan bukan secara amatiran. Profesionalisme bertentangan dengan amatirisme. Seorang profesional akan terus menerus meningkatkan mutu karya secara sadar, melalui pendidikan dan latihan. ${ }^{6}$ Lebih lanjut, menurut Martinis Yamin profesi mempunyai pengertian seseorang yang menekuni pekerjaan berdasarkan keahlian, kemampuan, teknik dan prosedur berdasarkan intelektualitas. ${ }^{7}$

Jamis Muhammad yang dikutip oleh Yunus Namsa, menjelaskan bahwa profesi adalah suatu lapangan pekerjaan yang dalam melakukan tugasnya memerlukan teknik dan prosedur ilmia, memiliki dedikasi serta cara menyikapi lapangan pekerjaan yang berorientasi pada pelayanan yang ahli. Masalah utama pekerjaan profesi adalah implikasi dan konsekuensinya jabatan terhadap tugas dan tanggung jawabnya. Tinggi rendahnya pengakuan profesionalisme tergantung kepada keahlian dan tingkat pendidikan yang ditempuh. ${ }^{8} \mathrm{Jabatan}$ guru sebagai suatu profesi menurut keahlian dan keterampilan khusus di bidang "okupasi" atau pekerjaan yang sekedar mencari nafkah, dengan modal pengetahuan dan keterampilan paspasang. Jabatan guru juga bukan sekedar "vokasional" atau kejuruan belaka. Guru adalah suatu jabatan profesional. ${ }^{9}$

Maka perwujudan kerja profesional guru ditunjang jiwa profesionalisme yang sikap mental yang senantiasa mendorong dirinya untuk mewujudkan diri sebagai guru profesional. Guru yang profesional tentu memiliki pengetahuan dan keterampilan yang langsung menyentuh masalah inti pendidikan, termasuk pengetahuan dan keterampilan mengenai caracara mengarahkan proses pertumbuhan yang terjadi dalam diri peserta didik yang sedang

\footnotetext{
${ }^{4}$ Muhammad Surya, Percikan Perjuangan guru (Bandung: Aneka Ilmu, 2003), 32.

${ }^{5}$ Kunandar, Guru Profesional Implementasi Kurikulum Tingkat Satuan Pendidikan (KTSP) dan Persiapan Menghadapi Sertifikasi Guru (Cet. I; Jakarta: Raja Grafindo Persada, 2007), 45.

${ }^{6}$ H.A.R. Tilaar, Memahami Pendidikan Nasional, (Cet. I; Jakarta: Rineka Cipta, 2002), 86.

${ }^{7}$ Kunandar, Guru Profesional ..., 80.

${ }^{8}$ Hadari Nawawi, Organisasi Sekolah dan Pengelolaan Kelas (Cet. Jakarta: CV. Haji Agung, 1989), 23.

${ }^{9}$ Ahmad Rohani, Pedoman penyelenggaraan Administrasi Pendidikan Sekolah (Cet. I; Jakarta: Rineka Cipta, 2002), 81.
} 
mengalami proses kependidikan. Pada dasarnya profesionalisme itu merupakan motivasi pada diri sebagai pendorong untuk mengembangkan dirinya kearah perwujudan profesional. ${ }^{10}$ Selanjutnya, Mukhtar mengungkapkan profil profesionalisme kemampuan dasar bagi mencakup:

a. Menguasai materi pembelajaran, baik dalam kurikulum maupun aplikasinya dalam materi pembelajaran.

b. Mampu mengelola program pembelajaran dengan merumuskan tujuan instruksional, mengunakan metode mengajar dan prosedur intruksional yang tepat, serta memahami kemampuan peserta didik.

c. Mampu mengelola kelas dan menciptakan iklim pembelajaran yang kondusif.

d. Mengunakan media atau sumber belajar, terutama dalam memanfaatkan media yang ada.

e. Menguasai landasan kependidikan, baik secara koseptual maupun secara praktikal.

f. Mampu mengelola interaksi dalam proses pembelajaran dan memberikan penilaian yang komprehensif. ${ }^{11}$

Berdasarkan penjelasan tersebut, guru merupakan tenaga pendidik yang profesional. Kemudian daripada itu, sikap profesional mengisyaratkan pentingnya upaya peningkatan kualitas secara terus menerus agar mampu menghadapi berbagai persoalan yang berkaitan dengan bidang keahliannya secara kontekstual. Lebih lanjut, guru yang profesional bukan hanya sekedar alat untuk trasmisi kebudayaan, tetapi menstranformasikan kebudayaan itu kearah budaya yang dinamis yang menuntut penguasaan ilmu pengetahuan, produktivitas yang tinggi, dan kualitas karya yang berdaya saing. ${ }^{12}$ Dengan demikian jelaslah bahwa profesionalisme guru merupakan komitmen guru untuk meningkatkan kemampuan profesionalnya dan terus menerus mengembangkan strategi yang digunakannya dalam melakukan pekerjaan sebagai pengakar (guru). Kematangan profesional guru ditandai dengan perwujudan guru yang memili keahlian, baik menyangkut materi keilmuan yang dikuasai maupun kemampuan metodologinya. Keahlian yang dimiliki oleh guru profesional diperoleh melalui suatu proses pendidikan dan latihan yang diprogramkan dan struktur secara khusus.

\section{Jenis-jenis Kompetensi Profesional Guru}

Profesi guru menuntut agar para guru senantiasa memiliki kemampuan atau kompetensi tersendiri dalam hal mendidik peserta didiknya. Kompetensi guru tersebut adalah salah satu syarat yang mesti dimiliki dan dikembangkan oleh guru profesional, karena tampa kemampuan atau kompetensi guru itu sulit tujuan pendidikan tercapai. Dalam rangka

\footnotetext{
${ }^{10}$ Surya, Percikan Perjuangan. . , 33.

${ }^{11}$ Mukhtar, Desain Pembelajaran Pendidikan Agama Islam (Cet. I; Jakarta: Bumi Aksara, 1991), 103.

12 Tilaar, Memahami Pendidikan . . , 80-81.
} 
mewujudkan tugas profesinya, guru mempunyai kewajiban untuk memiliki kompetensi pendidikan tertentu, yaitu:

\section{Kompetensi Profesional}

Kompetensi profesional adalah kompetensi yang memberikan peluang pada guru untuk menyelesaikan tugas-tugas keguruannya. Karena tidak mungkin para guru bisa menyelesaikan tugasnya tampa ada kompetensi profesional itu sangat berhubungan langsung dengan kerja yang ditampilkan. Oleh karena itu, tingkat keprofesionalan seorang guru dapat dilihat dari kompetensi ini, antara lain;

a. Kompetensi dalam menyusun rencana pembelajaran

b. Kompetensi dalam melakukan interaksi belajar mengajar

c. Kompetensi dalam penilaian peserta didik. ${ }^{13}$

Kompetensi yang diuraikan tadi, sangat membantu bagi guru sebagai pendidik untuk menyelesaikan segala sesuatu yang berkaitan dengan mengelola pembelajaran. Oleh karena itu, guru yang memiliki kompetensi profesional dan ditambah dengan kompetensi yang lain, maka akan memudahkan baginya, melaksanakan proses pembelajaran yang efektif. Kompetensi professional, merupakan unsur penting bagi seorang guru dalam melaksanakan tugas dan tanggung jawabnya. Bila seorang guru tidak professional, tentu dapat dipastikan kegiatan pembelajaran akan berlangusung dengan kurang maksimal dan secara tidak langung berpengaruh pada outcome peserta didiknya di tingkat satuan pendidikan.

\section{Kompetensi sosial}

Kompetensi ini sangat membatu guru untuk memahami keadaan masyarakat sosial. Adapun kemampuan tersebut:

a. Kemampuan untuk berinteraksi dan berkomunikasi dengan teman sejawat untuk meningkatkan kemampuan profesional.

b. Kemampuan untuk mengenal dan memahami fungsi-fungsi untuk setiap lembaga kemasyarakatan.

c. Kemampuan untuk menjalin kerja sama, baik individu maupun secara kelompok.

d. Mampu membiasakan mengikuti perkembangan profesi.

e. Mampu berinteraksi dengan masyarakat untuk penunaian misi pendidikan. ${ }^{14}$

Untuk melihat dan memahami keadaan atau krakter masyarakat yang kompleks, guru mesti memiliki kompetensi atau kemampuan dalam beradaptasi dan bergaul dengan mereka. Kemampuan seorang guru dalam memahami dan bergaul dengan masyarakat akan memberikan pengaruh yang positif terhadap proses pendidikan,

\footnotetext{
${ }^{13}$ Muhtar, Desain Pembelajaran Pendidikan Agama Islam (Cet. II; Jakarta: Misaka Galiza, 2003), 79.

${ }^{14}$ Ibid., 79.
} 
karena kerja sama dan dukungan masyarakat dalam proses pencapaian tujuan pendidikan adalah sesuatu yang sangat efektif.

\section{Kompetensi kepribadian}

Guru merupakan panutan masyarakat dan peserta didik, jika guru terutama guru agama tidak mencerminkan ilmu dalam prilaku kehidupannya, maka guru tersebut akan dilihat atau dinilai oleh masyarakat sebagai guru yang berakhlak buruk dan sebaliknya bila guru mengimplementasikan nilai ilmu dalam kehidupannya maka mereka akan dihormati, digugu dan ditiru oleh masyarakat. Oleh karena itu, kepribadian guru adalah salah satu indikator dalam pandangan atau penilaian masyarakat. Kepribadian seorang guru adalah hal mendasar yang melekat pada dirinya yang nampak dari keindahan tutur kata, sikap dan tindakan yang menunjukan uswatun hasanah. Istimewahnya seorang guru agama yang idealnya memiliki kepribadian yang manifestasikan keseluruhan ajaran agamanya, sehingga merekalah yang menjadi figur yang biasa dicontoh oleh peserta didik.

\section{Kompetensi Paedagogis}

Dalam Undang-Undang Guru dan Dosen menurut ketentuan umum dalam undang-undang ini dinyatakan bahwa: "Guru adalah pendidik profesional dengan tugas utama mendidik, mengajar, membimbing, mengarahkan, melatih, menilai dan mengevaluasi peserta didik pada usia dini jalur pendidikan formal, pendidikan dasar dan pendidikan menengah. ${ }^{15}$

Berdasarkan uraian di atas, jelaslah bahwa kompetensi guru sangat penting baik kompetensi paedagogik, kepribadian, kemasyarakatan dan profesional. Dengan kompetensi tersebut guru akan lebih mapan untuk meraih sertifikat yang bertujuan untuk meningkatkan tugas dan bermuara kepada tingkat kesejahteraan. Pengusaan keempat kompetensi tersebut dalam diri seorang guru termasuk guru pendidikan agama Islam merupakan indikator capaian yang dapat menggambarkan profesionalisme guru dalam melakasanakan kegiatan pembelajaran bagi anak didiknya di tingkat satuan pendidikan.

\section{Syarat-Syarat Guru Profesional Dalam Pendidikan Islam}

Menurut Al-Kanadi dalam Abd. Rahman Getteng mengemukakan persyaratan seorang pendidik terdiri dari tiga macam, yakni syarat yang berkenaan dengan diri sendiri, syarat yang berkenaan dengan pelajaran pedagogis didaktis dan syarat yang berkenaan dengan peserta didiknya.

\section{Syarat yang berkenaan dengan dirinya, yaitu:}

${ }^{15}$ Lihat Undang-undang RI Nomor 14 Tahun 2005 Tentang tentang Guru dan Dosen (Jakarta: 2005), 3. 
a. Guru hendak bersifat zuhud;

b. Guru hendak tidak tamak terhadap kesenangan duniawi;

c. Guru hendaknya tidak mengkomersiakan ilmunya untuk kepentingan sesaat;

d. Guru hendaknya menghindari hal-hal yang hina menurut pandangan syarah;

e. Guru hendaknya menjauhi hal-hal yang mendatangkan fitnah;

f. Guru hendaknya senantiasa memelihara syiar-syiar Islam;

g. Guru hendaknya senantiasa bersabar dan tegar dalam menghadapi celaan dan cobaan-cobaan;

h. Guru hendaknya senantiasa mengisi waktu-waktu luangnya dengan hal-hal yang bermanfaat;

i. Guru hendaknya selalu tekun menambah ilmunya.

\section{Syarat yang berhubungan dengan pelajaran yaitu:}

a. Guru hendaknya mengenakan pakaian yang bersih dan rapi;

b. Guru hendaknya mengenakan pakaian yang bersih dan rapi;

c. Guru hendaknya berdoa agar tidak sesat dan menyesatkan;

d. Guru hendaknya senantiasa berzikir kepada Allah hingga sampai majlis pelajaran;

e. Guru hendaknya memiliki amanah ilmia;

f. Guru hendaknya mengajarkan pelajaran sesuai dengan keahliannya;

g. Guru hendaknya menjaga ketertiban majlis;

h. Guru hendaknya bersikap bijak dalam seluruh proses pembelajaran;

i. Guru hendaknya menutup kegiatan dalam proses pembelajaran dengan kata wallau-a'alam (Allah yang maha tahu).

\section{Syarat yang berkaitan dengan peserta didik yaitu:}

a. Guru hendaknya mengajar dengan berniat untuk mendapat ridha Allah;

b. Guru hendaknya senantiasa menghidupkan syarat;

c. Guru hendaknya senantiasa menyebarkan ilmu;

d. Guru hendaknya memotivasi peserta didiknya untuk menuntut ilmu seluasluasnya;

e. Guru hendaknya mempersiapkan pelajaran yang muda dipahami;

f. Guru hendaknya bersikap adil terhadap semua peserta didik;

g. Guru hendaknya memperhatikan tingkat perkembangan dan pemahaman peserta didik;

h. Guru hendaknya melakukan evaluasi terhadap kegiatan belajar peserta didik. ${ }^{16}$

Meski demkian, untuk mewujudkan syarat-syarat tersebut, tidak semudah membalikan telapak tangan, tapi butuh kesabaran dan latihan yang terus menerus dalam mengembangkan

\footnotetext{
${ }^{16}$ Rahman Getteng, Menuju Guru Profesional dan Ber-Etika (Cet. 7 : Yogyakarta : Graha Guru : 2012),
} 61. 
potensi yang dimilikinya. Karena guru profesional itu adalah guru yang betul-betul tanggung jawab sebagai pendidik, sehingga dengan tanggung jawab itu, memberikan semangat yang tinggi bagi dirinya untuk senantiasa meningkatkan kualitas pengetahuannya. Selain itu, konsep pendidikan Islam sangat menganjurkan kepada umatnya untuk senantiasa melakukan proses pembelajaran yang baik dan benar, dengan penuh kesabaran dan ketabahan. Sifat tersebut sangat membantu para guru dalam mencapai hasil yang memuaskan dalam proses pembelajarannya. Dengengan demikian,sesungguhnya pendidik profesional adalah pendidik yang memiliki persyaratan tertentu, seperti bekerja penuh, memiliki ilmu pengetahuan, ilmunya dapat diaplikasikan, ilmu didapat dari lembaga pendidikan.

\section{Tanggung Jawab Profesional Guru PAI dalam Menanamkan Akhlak Mulia Peserta Didik}

Pendidikan agama Islam adalah sebuah sistem pendidikan integratif dan terdiri dari sejumlah komponen yang saling berkaitan. Pemberian bimbingan, pengajaran dan latihan diberikan secara terstruktur dan memiliki kejelasan arah pembentukan. Masyarakat muslim dibentuk dengan sejumlah aspek pendidikan termasuk di antaranya pengalaman, pengetahuan, kecakapan dan keterampilan. Pembentukan yang diharapkan dapat memunculkan terhadap kepribadian yang utuh dalam diri setiap muslim. Pola kepribadian yang utuh adalah manusia muslim yang mampu mengaplikasikan nilai-nilai keislaman dalam kehidupannya.

Merujuk penjabaran Peraturan Menteri Agama nomor 16 tahun 2010, pasal 1 ayat 1 menyatakan bahwa: pendidikan agama adalah pendidikan agama yang memberikan pengetahuan dan pembentukan sikap, kepribadian, dan keterampilan peserta didik dalam mengamalkan ajaran agamanya, yang dilaksanakan sekurang-kurangnya melalui mata pelajaran/kulia pada semua jalur, jenjang dan jenis pendidikan. ${ }^{17}$ Pendidikan agama adalah satu strategi yang sangat baik dalam penanaman moral, karena ajaran agama syarat dengan nilai-nilai moral, sehingga bila terbiasa menjalankan aturan-aturan agama (pendidikan agama), maka dari segi akhlak atau moralnya tidak diragukan apalagi bila ditopang oleh lingkungan yang memadai, maka jiwa dan raga peserta didik tersebut selalu terbiasa melakukan hal-hal yang benar sesuai dengan ajaran agama. Berkaitan dengan pendidikan agama di sekolah, M. Athiyah al-Abrasyi memberi pengertian guru sebagai spiritual father atau bapak rohani bagi seorang murid, ialah yang memberikan santapan jiwa dengan ilmu pendidikan akhlak. ${ }^{18}$

\footnotetext{
${ }^{17}$ Lihat Peraturan Menteri Agama RI nomor 16 tahun 2010, tentang Pengelolaan Pendidikan Agama pada sekolah.

${ }^{18}$ M. Athiyah al-Abrasy, Al-Tarbiyah al-Islamiyah. Terj. Bustami, dkk., Dasar -Dasar Pendidikan Islam (Jakarta: Bulan Bintang, 1990), 136.
} 
Guru agama yang bertanggung jawab tidak hanya berusaha mentrasferkan ilmu pengetahuan kepada peserta didiknya, tetapi juga berusaha juga mengisi jiwa mereka dengan nilai-nilai keimanan. Dengan demikian, satu hal yang tak kalah penting dalam penanaman akhlak mulia peserta didik tidak hanya dibentuk melalui intruksi dan larangan tetapi melalui mencotohkanya dalam sikap, tingkah laku dan perbuatan. Selain itu, keteladanan sangat penting bagi penanaman akhlak, karena guru adalah tokoh yang menjadi idola peserta didiknya. Berdasarkan tersebut, maka dapat disimpulkan bahwa guru pendidikan agama Islam adalah orang yang bertanggung jawab untuk mencerdaskan kehidupan peserta didiknya, baik dalam perkembangan jasmani atau rohani agar mencapai kedewasaanya. Untuk itulah guru dengan penuh dedikasi dan loyalitas berusaha membimbing dan membina peserta didik agar di masa mendatang menjadi orang yang berguna yang cerdas, yaitu cerdas intelektual, cerdas emosi dan juga cerdas spiritual.

Menurut Hamdani dan H. A. Fuad Ihsan bahwa guru atau pendidik dalam agama Islam adalah orang dewasa yang bertanggung jawab memberi bimbingan atau bantuan kepada peserta didik dalam perkembangan jasmi dan rohaninya agar mencapai kedewasaannya, maupun melaksanakan tugasnya sebagai makhluk Allah SWT, menjadi khalifah di permukaan bumi, sebagai makhluk sosial dan sebagai individu yang sanggup berdiri sendiri. ${ }^{19}$ Bahkan dalam ranah praksis, seorang guru pendidikan agama Islam, diharuskan unuk memeiliki peranan yang signifikan dalam mengajar dan menanamkan masalah pentingnya nilai akhlah dalam diri seorang anak didik di lingkungan pendidikan secara profesional.

\section{Konsep Dasar Guru PAI dalam Menanamkan Akhlak Mulia Peserta Didik}

Selain hakikat tanggung jawab profesional seorang guru dalam menanamkan akhlak kepada pesesrta didik di setiap tingkat satuan pendidikan, namun sisi lain yang mesti diperhatikan oleh seorang guru yakni seberapa besar pemahaman seorang guru dalam mengkontekstualkan pelaksanaan penanaman akhlak mulia kepada peserta didik. Sehubungan dengan hal tersebut ada beberapa hal yang harus dipahami oleh guru sebagai landasan ideal dalam menanamkan akhlak mulia peserta didik, antara lain:

\section{Akhlak Peserta Didik}

Akhlak secara etimologi berasal dari bahasa Arab dengan kata dasar (khalakah) yang berarti mencipta, membuat atau menjadikan. ${ }^{20}$ Kamus besar bahasa Indonesia, kata "akhlak" diartikan budi pekerti, kelakuan, tingkah laku atau tabiat. ${ }^{21}$ Sebagaimana

\footnotetext{
2011), 93.

${ }^{19}$ Hamdani Ihsan dan H. A F uad Ikhsan, Filsafat pendidikan Islam (Cet. II; Bandung; Pustaka Setia,

${ }^{20}$ Achmad Warson Munawir, Kamus Arab Indonesia (Cet. 4; Surabaya: Pustaka Progresif, 1997), 363.

${ }^{21}$ Republik Indonesia, Kamus Bahasa Indonesia Pusat Bahasa (Cet. I edisi IV; Jakarta: 2008), 26.
} 
di ensiklopedi Islam, kata akhlak diartikan; "(1) tabiat, budi pekerti, (2) kebiasaan atau adat, (3) kepewiraan, kesatriaan, kejantanan, (4) agama, dan kemarahan. ${ }^{22}$ Kata akhlak merupakan serapan dari bahasa Arab, mempunyai arti yang banyak dalam bahasa Indonesia yang intinya mempunyai arti makna yang sama. Arti dari kata akhlak tidak ditemukan penggunaannya dalam al-Qur'an, yang ditemukan hanya bentuk tunggal dari kata khuluq.

Selanjutnya, kalau dilihat dari fungsi dan peranannya seperti etika moral, susila dan akhlak sama, yaitu menentukan hukum atau nilai dari suatu perbuatan yang dilakukan manusia untuk ditentukan baik buruknya. ${ }^{23}$ Sebernanya kesemuanya itu mengharapkan terbentuk keadaan masyarakat yang baik, teratur, tentram, aman, damai dan sejahtera lahir dan batin. Akhlak bukan saja tata aturan atau norma perilaku yang mengatur hubungan antara sesama manusia, tetapi juga norma yang mengatur hubungan antara sesama manusia dengan tuhan dan bahkan dengan alam semesta sekalipun. ${ }^{24}$ Akhlak secara bahasa bisa baik dan bisa buruk tergantung tata nilai yang dipakai sebagai landasannya, meskipun secara sosiologis di Indonesia kata akhlak sudah digantung konotasi baik, jadi orang yang berakhlak berarti orang yang berakhlak baik. ${ }^{25}$ Satu Alang mengatakan akhlak adalah perbuatan yang dilakukan secara sepontanitas, yang timbul karena dorongan emosi jiwanya, bukan karena adanya tekanan-tekanan yang datang dari luar dirinya. ${ }^{26}$ Akhlak adalah suatu kondisi atau sifat yang telah meresap dalam jiwa dan telah menjadi kepribadian, dengan timbulnya berbagai macam perbuatan dengan cara spotan tampa dibuat-buat dan tampa memerlukan pikiran. Sekalipun definisi netral, belum menunjukan kepada baik dan buruk, tetapi pada umunya bila kata tersebut sendirian dan tidak dirangkai dengan kata tertentu, maka dimaksud dengan akhlak yang baik (mulia). Contohnya bila seorang berlaku tidak sopan maka dikatakan kepadanya "kamu tidak berakhlak" atau dikatakan "kurang ajar", padahal tidak sopan dan kurang ajar itu adalah akhlaknya dalam hal ini tidak sopan santun.

\section{Pembagian akhlak}

Masalah akhlak sangat mendapat perhatian yang besar, khususnya dalam ajaran Islam yang berkaitan dengan akhlak baik dan buruk. Al-Qur'an dan Hadis merupakan sumber ajaran Islam yang eksklusif dan tertutup. Kedua sumber tersebut bersikap terbuka untuk menghargai bahkan menampung pendapat akal pikiran, adat istiadat dan sebagainya yang dibuat manusia, dengan catatan semua itu tetap sejalan dengan petuju al-Qur'an dan al- al-Hadis. Ketentuan baik dan buruk yang didasarkan pada logika dan

${ }^{22}$ Dewan Redaksi, Ensiklopedi Islam ( Cet. 4; Jakarta Ichtiar Baru, 2001, 2001), 102.

${ }^{23}$ Abuddi Nata, Akhlak Tasawu (Ed. I Jakarta: Grafindo Persada, 2009), 240.

${ }^{24}$ Yuhanar Ilyas, Kulia Akhlak ( Cet. VIII; Yogyakarta: LPPI UMY, 2006), 1.

${ }^{25}$ Zakiah Daradjat, Dasar-Dasar Agama Islam (Cet. 10; Jakarta: Bulan Bintang, 1996), 238.

${ }^{26}$ Sattu Alang, Kesehatan Mental dan Terapi Islam (Cet. II; Makassar: Berkah Utami, 2005), 99. 
filsafat dengan berbagai alirannya berupa etika, atau ketentuan baik dan buruk yang terdapat dalam etika dan moral dapat digunakan sebagai sarana atau alat untuk menjabarkan ketentuan baik dan buruk yang ada dalam al-Qur'an. Secara garis besar pembagian akhlak dalam Islam ada dua macam, yaitu akhlak yang baik (al-ahklaq alkarimah) dan akhlak yang buruk (al-akhlak al-mazmumah). ${ }^{27}$

\section{a. Akhlak yang baik (al-Akhlak al-karimah)}

Akhlak yang baik atau akhlakul karimah yaitu sistem nilai yang menjadi asas prilaku yang bersumber dari al-Qur'a, Hadis dan nilai-nilai alamiah (sunatullah). ${ }^{28}$ Sementara itu harun nasation mengatakan bahwa orang yang bertakwa adalah orang yang berakhlak mulia. Takwa di sini berarti melaksanakan perintah Tuhan dan menjauhi laranganNya. Jadi orang yang bertakwa adalah orang yang melaksanakan perintah Tuhan dan menjauhi laranganNya, yaitu orang berbuat baik dan jauh dari perbuatan tidak baik atau yang disebut amar ma'ruf dan nahi mungkar. ${ }^{29}$

Begitu pentingnya akhlak mulia, karena akhlak mulia itu merupakan tolak ukur kesempurnaan iman seseorang dan iman dalam konsep ajaran Islam identik dengan spiritual keagamaan yang berfungsi sebagai fondasi akidah bagi setiap muslim dalam melakukan aktivitasnya. Dalam rangka menciptakan generasi bangsa dan generasi yang bermoral dan berakhlak mulia, maka peserta didik salah satu syarat utama yang perlu diperhatikan akhlaknya karena mereka adalah generasi penerus bangsa.

\section{b. Akhlak yang buruk (al-Akhlaq al-Mazmumah)}

Akhlak yang buruk adalah akhlak yang sangat jelas dibenci oleh manusia dan sistem nilai tersebut sangat bertentangan dengan sumber al-Qur'an dan alHadis. Hal ini seperti tertuang dalam firman Allah swt. Surat al-Hijir/15: Terjemahnya: Iblis berkata: "Ya Tuhanku, oleh sebab Engkau telah memutuskan bahwa aku akan sesat, baik (perbuatan ma'siat) di muka bumi, dan pasti Aku akan menyesatkan mereka semuanya, kecuali hamba-hamba engkau yang mukhlis di antara mereka" ${ }^{\prime 30}$

\section{Metode Pendidikan Akhlak terhadap Anak/Peserta didik}

Sesungguhnya bagi para guru PAI dalam lingkup satuan pendidikan mengajarkan tentang akhlak kepada anak/peserta didiknya merupakan suatu keharusan, bahkan dalam implementatifnya pengajaran pendidikan Agama Islam seyogyanya sangat menekanan prinsip dasar pembinaan nilai Akhlak dalam diri seorang anak terutama

\footnotetext{
${ }^{27}$ Imam al-Gazali, Ihya Ulum al-Din (Jilid III), 59.

${ }^{28}$ Zainuddin Ali, Pendidikan Agama Islam (Cet. IV; Jakarta: Bumi Aksara, 2011), 31.

${ }^{29}$ Harun Nasution, Islam Rasional: Gagasan dan Pemikiran (bandung: Mizan, 1995), 57.

${ }^{30}$ Departemen Agama RI, Al-Qur'an dan Terjemahnya (Surabaya: Mekar Surabaya, 2008), 70.
} 
gagasan akhlak yang berkenaan dengan akhlak kepada Allah SWT, akhlak kepada kedua orang tua, akhlak kepada orang lain, maupun konsep akhlak kepda diri sendiri. Meski demikain, pembentukan serta pembinaan ragam akhlak tersebut keepda anak didik juga mesti diimbangi dengan pendekatan atau metode pengajaran yang dapat dilakukan oleh orang tua termasuk seorang guru dilingkungan pendidikan selaku unit sosial dalam proses pembentukan prilaku seorang anak/ peserta didik. Dalam hal ini, bila merujuk penjabaran Amin Zamroni disebutkan terdapat beberapa metode penanaman akhlak kepada anak didik/pesert didik sebagai berikut: ${ }^{31}$

\section{a. Metode Keteladanan (Uswatun Hasanah)}

Keteladanan dalam pendidikan adalah metode yang paling meyakinkan keberhasilannya dalam mempersiapkan dan membentuk anak di dalam moral, spiritual dan sosial. Hal ini karena pendidik adalah contoh terbaik dalam pandangan anak yang akan ditirunya dalam tindak-tanduknya dan tata santunnya, disadari ataupun tidak, bahkan tercetak dalam jiwa dan perasaan suatu gambaran pendidik tersebut, baik dalam ucapan ataupun dalam perbuatan, baik material atau spiritual, diketahui atau tidak diketahui. Masalah keteladanan menjadi faktor penting dalam hal buruknya anak. Jika pendidik jujur, dapat dipercaya, berakhlak mulia, berani dan manjauhkan diri dari perbuatan yang bertentangan dengan agama, maka anak akan tumbuh dalam kejujuran, terbentuk dengan akhlak mulia, keberanian dan dalam sikap yang menjauhkan diri dari perbuatan-perbuatan yang bertentangan dengan agama. Tetapi, jika pendidik bohong, khianat, durhaka, kikir, penakut, dan hina, maka si anak akan tumbuh dalam kebohongan, khianat, durhaka, kikir, penakut dan hina. ${ }^{32}$

\section{b. Metode Pembiasaan}

Sejak kecil anak harus dibiasakan untuk melakukan kegiatan-kegiatan yang baik, dilatih untuk bertingkah laku yang baik, diajari sopan santun dan sebagainya. Mendidik, melatih, dan membimbing anak secara perlahan adalah hal yang wajib diterapkan pada anak agar dia dapat meraih sifat dan ketrampilan dengan baik, agar keyakinan dan akhlaknya tertanam dengan kokoh. Akhlak dan prinsipprinsip keyakinan, termasuk di dalamnya ketrampilan anggota tubuh, membutuhkan adanya proses bertahap untuk dapat diraih dan harus dilakukan secara kebiasaan atau berulang-ulang sehingga tercapai dan dikuasai dengan baik, serta dapat dilaksanakan dengan mudah dan ringan, tanpa bersusah payah dan menemukankesulitan. Anak merupakan anugerah sekaligus amanat yang diberikan Allah kepada manusia yang menjadi orang tuanya. Hatinya masih

${ }^{31}$ Lihat Amin Zamroni, Strategi Pendidikan Akhlak Kepada Anak (Jurnal SAWWA Vol. 12, Nomor 2, April 2017), 254.

32 Ibid, 255. 
bersih dan suci. Baik dan buruknya seorang anak tergantung dari pendidikan yang diberikan kepadanya. ${ }^{33}$

\section{c. Metode Nasihat (Mau'izhah al-Hasanah)}

Nasihat dapat membukakan mata anak-anak pada hakikat sesuatu, mendorongnya menuju situasi luhur, menghiasi dengan akhlak yang mulia dan membekalinya dengan prinsip-prinsip Islam. Metode al-Qur'an dalam menyerukan dakwaan adalah bermacam-macam. Semua itu dimaksudkan sebagai upaya mengingat Allah menyampaikan nasihat dan bimbingan, yang semuanya berlangsung atas ucapan para Nabi as. Kemudian, dituturkan kembali oleh para da'i, dari kelompok dan pengikutnya. Nasihat yang tulus membekas dan berpengaruh, jika memasuki jiwa yang bening, hati terbuka, akal yang bijak, maka nasihat tersebut akan mendapat tanggapan secepatnya dan meninggalkan bekas yang dalam. al-Qur'an telah menegaskan pengertian ini dalam banyak ayatnya dan berulang kali menyebutkan manfaat dari peringatan. Allah berfirman: "Sesungguhnya pada yang demikian itu benar-benar terdapat per-ingatan bagi orang-orang yang mempunyai akal atau yang mengguna- kan pendengarannya, sedang Dia menyaksikannya." (QS. Qaaf [50]: 37)

\section{d. Metode Perhatian}

Metode pendidikan dengan perhatian adalah mencurahkan, memperhatikan dan senantiasa mengikuti perkembangan anak dalam pembinaan akidah dan akhlak, persiapan spiritual dan sosial selain itu juga bertanya tentang situasi pendidikan jasmani dan daya hasil ilmiahnya. Metode perhatian ini merupakan metode pendidikan yang terkuat dalam pembentukan manusia secara utuh dan dapat mendorongnya untuk menunaikan tanggung jawab dan kewajibannya secara sempurna. Melalui upaya tersebut akan tercipta Muslim yang hakiki. Allah berfirman: "Hai orang-orang yang beriman, peliharalah dirimu dan keluargamu dari api neraka yang bahan bakarnya adalah manusia dan batu; penjaganya malaikat-malaikat yang kasar, keras, dan tidak mendurhakai Allah terhadap apa yang diperintahkan-Nya kepada mereka dan selalu mengerjakan apa yang diperintahkan." (QS. al-Tahrim [66]: 6) ${ }^{34}$

\footnotetext{
${ }^{33}$ Ibid, 256.

${ }^{34}$ Ibid, hlm. 257.
} 


\section{Penutup}

Tinggi rendahnya kualitas pendidikan sangat ditentukan oleh kualitas kenerja dan profesional guru. Sebagai pendidik dan pengajar di lembaga pendidikan formal, khusus guru Pendidikan Agama Islam memiliki fungsi dan peran penting dalam meningkatkan kualitas akhlak peserta didiknya. Hal tersebut dapat dilihat dari kenerja dan tanggung jawab guru dalam mengajar dan menanamkan nilai akhlak mulia peserta didik. Tanggung jawab guru dalam mengajar dan menanamkan akhlak peserta didik bertujuan untuk meningkat kualitas pengetahuan serta akhlak peserta didik, maka proses pengajaran dan penanaman akhlak harus dilakukan secara profesional. Seorang guru pendidikan agama Islam yang profesional juga harus memposikan diri sebagai agen pembahru dengan menyadari secara penuh terkait tanggung jawab moral dalam membentuk karakter serta menanamkan nilai-nilai akhlak Islamiyah dalam diri seorang didik.

Adapun bentuk akhlak yang mesti tertanan dalam diri peserta didik mencakup tabiat, budi pekerti, kebiasaan atau adat, kepewiraan, kesatriaan, kejantanan, agama, dan kemarahan yang dapat mencerminkan sikap baik dari aspek rohani dan jasmani seorang anak didik. Sehingga, dapat disimpulkan bahwa guru pendidikan agama Islam adalah orang yang bertanggung jawab untuk mencerdaskan kehidupan peserta didiknya, baik dalam perkembangan jasmani atau rohani agar mencapai kedewasaanya. Untuk itulah guru dengan penuh dedikasi dan loyalitas berusaha membimbing dan membina peserta didik agar di masa mendatang menjadi orang yang berguna yang cerdas, yaitu cerdas intelektual, cerdas emosi dan juga cerdas spiritual di lingkup satuan pendidikan.

\section{Daftar Pustaka}

Alang, Sattu Kesehatan Mental dan Terapi Islam Cet. II; Makassar: Berkah Utami, 2005. Al-Gazali, Imam. Ihya Ulum al-Din ,Jilid III.

Ali, Zainuddin. Pendidikan Agama Islam; Cet. IV; Jakarta: Bumi Aksara, 2011.

Dewan Redaksi, Ensiklopedi Islam Cet. 4; Jakarta Ichtiar Baru, 2001.

DPR RI, Undang-undang RI Nomor 14 Tahun 2005 Tentang Guru dan Dosen, Jakarta: 2005. Daradjat, Dakiah. Dasar-Dasar Agama Islam Cet. 10; Jakarta: Bulan Bintang, 1996.

Departemen Agama RI, Al-Qur'an dan Terjemahnya; Surabaya: Mekar Surabaya, 2008.

Getteng, Abd. Rahman. Menuju Guru Profesional dan Ber-etika Cet. VII; Yogyakarta: Graha Guru, 2012.

Hamdani Ihsan dan H. A F uad Ikhsan, Filsafat pendidikan Islam (Cet. II; Bandung; Pustaka Setia, 2011), h.93.

Kunandar, Guru Profesional Implementasi Kurikulum Tingkat Satuan Pendidikan (KTSP)dan Persiapan Menghadapi Sertifikasi Guru Cet. I; Jakarta: Raja Grafindo Persada, 2007.

Munawir, Achmad, Warson, Kamus Arab Indonesia Cet. 4; Surabaya: Pustaka Progresif, 1997. 
Nawawi, Hadari. Organisasi Sekolah dan Pengelolaan Kelas Cet. Jakarta: CV. Haji Agung, 1989.

Nasution, Harun. Islam Rasional: Gagasan dan Pemikiran ; Bandung: Mizan, 1995.

Ilyas, Yuhanar. Kulia Akhlak; Cet. VIII; Yogyakarta: LPPI UMY, 2006.

Permenag RI nomor 16 tahun 2010, tentang pengelolaan Pendidikan Agama pada sekolah, pasal 1 ayat 1. Republik Indonesia, Undang-Undang RI No. 20 tahun 2003 tentang Sistem Pendidikan Nasional Cet. IV; Sinar Grafika, 2011.

Republik Indonesia, Kamus Bahasa Indonesia Pusat Bahasa Cet. I edisi IV; Jakarta: 2008.

Rahim, Husni. Pengembangan Profesional dan Petunjuk Penulisan Karya Ilmiah, Cet. I: Jakarta: Dirjen kelembagaan Agama Islam, 2001.

Tilaar, H.A.R. Memahami Pendidikan Nasional, Cet. I; Jakarta: Rineka Cipta, 2002.

Surya, Muhammad. Percikan perjuangan guru, Bandung: Aneka Ilmu, 2003.

Undang-Undang RI No. 14 Tahun 2005 Tentang Guru dan Dosen; Jakarta: Cemerlang, 2007.

Muhtar. Desain Pembelajaran Pendidikan Agama Islam Cet. II; Jakarta: Misaka Galiza, 2003.

Zamroni, Amin. Strategi Pendidikan Akhlak Kepada Anak (Jurnal SAWWA Vol. 12, Nomor 2, April 2017.

M. Athiyah al-Abrasy, Al-Tarbiyah al-Islamiyah. Terj. Bustami, dkk., Dasar-Dasar Pendidikan Islam Jakarta: Bulan Bintang, 1990.

Nata, Abuddi. Akhlak Tasawu. Ed. I Jakarta: Grafindo Persada, 2009. 